\title{
O VALOR PROBATÓRIO DO INQUÉRITO POLICIAL
}

\author{
Caio Cezar Mareco de Souza, Eduardo Buzetti Eustachio Bezerro
}

Universidade do Oeste Paulista - UNOESTE, Curso de Direito, Presidente Prudente/SP. E-mail: caio_mareco@hotmail.com

\begin{abstract}
RESUMO
Este artigo conceitua inquérito policial fazendo uma breve explanagem sobre sua evolução histórica, demonstrando seu procedimento, bem como sua finalidade e seu valor probatório diante do cenário jurídico atual e da PEC 89/2015, que altera a Constituição Federal para dispor sobre a reforma do sistema de persecução penal, dando-lhe novas providências e restabelecendo o modelo de Policia Judiciária. Apresenta cada uma das fases da persecução penal e as principais diligências que devem ser adotadas pela autoridade policial para iniciar uma investigação preliminar e as formas de instauração do inquérito policial. O objetivo deste trabalho é expor as divergências doutrinárias e esclarecer dúvidas acerca do valor probatório do inquérito. Foi desenvolvido através do levantamento bibliográfico doutrinário, utilizando-se métodos dialéticos e dedutivos, os quais possibilitaram concluir que o inquérito policial recebeu certa valoração e que o magistrado pode valer-se das provas nele produzidas e de seu livre convencimento para sentenciar.
\end{abstract}

Palavras-chave: Inquérito policial. Persecução penal. Investigação preliminar. Provas Valor probatório.

\section{THE PROBATIVE VALUE OF THE POLICE INVESTIGATION}

\begin{abstract}
This article conceptualizes police investigation with a brief explanagem on its historical evolution, demonstrating their procedure as well as its purpose and its probative value given the current legal scenario and PEC 89/2015 amending the Constitution to provide for the reform of the system criminal prosecution, giving you new measures and restoring the Judicial Police model. It presents each phase of the criminal prosecution and the main steps that should be taken by the police to initiate a preliminary investigation and the forms of establishment of the police investigation. The objective of this work is to expose the doctrinal differences and clarify doubts on the probative value of the survey. It was developed through doctrinal literature, using dialectical and deductive methods, which made it possible to conclude that the police investigation received some assessment and the magistrate may make use of the evidence produced it and its free conviction to sentence.
\end{abstract}

Keywords: Police investigation. Criminal prosecution. Preliminary investigation. Evidence probative value. 


\section{INTRODUÇÃO}

O inquérito policial é um procedimento administrativo e investigatório, que tem por finalidade a apuração de um fato definido como crime, visando identificar indícios de autoria e provas da materialidade do delito para que Ministério Público possa ingressar com uma ação penal.

As provas produzidas na fase do inquérito, segundo a doutrina, não tem o condão de influenciar no convencimento do juiz no momento de proferir a sentença condenatória. Com efeito, todas elas deverão ser repetidas na fase processual, sobre o crivo do contraditório e da ampla defesa, para que possam servir de fundamento para uma eventual condenação.

Muito embora alguns doutrinadores afirmem que as provas produzidas no inquérito possuem valor relativo, existem aqueles que defendem que essas deveriam servir de base para que o juiz possa sentenciar sem a necessidade de serem repetidas em juízo, levando-se em consideração o Princípio do Livre Convencimento Motivado estampado no artigo 155 do Código de Processo Penal.

Com a proposição da PEC 89/2015, que reforma o sistema da persecução, dando-lhe novas providências, o inquérito policial terá novos parâmetros, que, por sua vez, passará a ser elaborado sobre o crivo do contraditório e da ampla defesa, tendo a mesma função do processo hoje conhecido.

Esta Proposta de Emenda Constitucional não incide somente na persecução penal, ela confere também às policias civis e militares o poder de investigação em ciclo completo, podendo estas iniciar e concluir suas investigações. Destarte, transforma-se o cargo de Delegado de Polícia em Juiz de instrução e garantias, função que já exercem na prática. Sendo assim, esse novo procedimento mostra-se eficaz, uma vez que nos traz celeridade e economia processual, pois, pelo que é apresentado, pretende-se fazer uma fusão do inquérito policial com o processo.

Assim, com proposta de modificação da legislação, houve uma má interpretação sistemática por parte dos doutrinadores acerca da letra da lei, gerando divergências de entendimentos e muitas dúvidas em relação ao valor probatório, que precisam ser esclarecidas através de uma análise minuciosa e de uma exposição organizada de ideias, sendo este o objetivo do presente artigo, a fim de proporcionar melhor entendimento sobre o assunto. 


\section{METODOLOGIA}

O presente trabalho foi desenvolvido através do levantamento bibliográfico doutrinário, utilizando-se os métodos dialéticos e dedutivos, os quais possibilitaram uma compreensão do tema para que desse suporte a eventuais discussões e chegar a possíveis conclusões.

\section{INQUÉRITO POLICIAL}

\section{Evolução Histórica}

Pelo que se entende pelos ensinamentos de José Fabio Rodrigues Maciel (2006, p.01), o inquérito policial surgiu após o período da inquisição, onde predominava o império dos Tribunais Eclesiásticos. Nesse período, a investigação e a punição de quem atentasse contra a ordem da sociedade eram comandadas por este juiz, que também era o responsável pela produção das provas, que eram coletadas de modo sigiloso, sendo ele mesmo quem acusava, defendia e julgava o individuo.

O procedimento denominado inquérito policial surgiu no Brasil através da lei no. 2033, de 20 de setembro de 1871, regulamentada pelo decreto №. 4.824, de 22 de novembro de 1871, onde em seu artigo 42 dispunha que "o inquérito policial consiste em todas as diligências necessárias para o descobrimento de fatos criminosos, de suas circunstâncias e de seus autores e cúmplices, devendo ser reduzido a instrumento escrito". (PICOLIN. 2007, p.01)

Ressalta o mesmo autor que décadas depois, surge o Código de Processo Penal (1941), onde manteve o instituto do inquérito, pois, se tratava de instrumento de garantia da população, sendo mantido também pela constituição Federal de 1988, a qual delimitou os princípios aplicáveis ao mesmo, bem como as garantias constitucionais de proteção ao individuo.

\section{Conceito}

O inquérito policial é um procedimento investigatório, presidido pelo Delegado de Polícia e tem como principal finalidade a apuração de um fato constituído como crime ou contravenção, e é feito através da colheita de provas da materialidade e indícios de autoria, que permitirão o Ministério Público, titular da ação penal, formar a sua opinio delicti, oferecendo denúncia contra o autor daquele crime.

Bonfim (2011, p. 144) entende que inquérito policial é:

Um procedimento administrativo, preparatório e inquisitivo, presidido pela autoridade policial, e constituído por um complexo de diligências realizadas pela polícia, no exercício da função judiciária, com vistas à apuração de uma infração penal e à identificação de seus autores. 


\section{Procedimento}

Os atos primordiais que ensejam a instauração do inquérito policial devem compilar-se em uma ordem sequencial, dando ensejo a um procedimento ordenado, que, por conseguinte, terá início, meio e fim. $\mathrm{O}$ artigo 60 do Código de Processo Penal, estabelece alguns parâmetros que podem ser observados, senão vejamos:

Art. 60 - Logo que tiver conhecimento da prática da infração penal, a autoridade policial deverá:

I - dirigir-se ao local, providenciando para que não se alterem o estado e conservação das coisas, até a chegada dos peritos criminais;

II - apreender os objetos que tiverem relação com o fato, após liberados pelos peritos criminais;

III - colher todas as provas que servirem para o esclarecimento do fato e suas circunstâncias;

IV - ouvir o ofendido;

V - ouvir o indiciado, com observância, no que for aplicável, do disposto no Capítulo III do Título VII, deste Livro, devendo o respectivo termo ser assinado por duas testemunhas que Ihe tenham ouvido a leitura;

$\mathrm{VI}$ - proceder a reconhecimento de pessoas e coisas e a acareações;

VII - determinar, se for caso, que se proceda a exame de corpo de delito e a quaisquer outras perícias;

VIII - ordenar a identificação do indiciado pelo processo datiloscópico, se possível, e fazer juntar aos autos sua folha de antecedentes;

IX - averiguar a vida pregressa do indiciado, sob o ponto de vista individual, familiar e social, sua condição econômica, sua atitude e estado de ânimo antes e depois do crime e durante ele, e quaisquer outros elementos que contribuírem para a apreciação do seu temperamento e caráter.

Desse modo, emerge da interpretação legislativa que, ocorrida a infração penal, e tão logo a Autoridade Policial tenha conhecimento, deverá iniciar os atos investigatórios, com vistas à elucidação da materialidade e autoria delitivas.

\section{Formas de Instauração:}

a) De ofício - Portaria do Delegado: a autoridade policial ao tomar conhecimento da ocorrência de um delito, seja verbal ou por escrito, imediatamente iniciar as investigações. $O$ primeiro passo para o inicio do inquérito é a realização da portaria expedida pelo delegado de polícia. Por meio de tal peça é que a autoridade policial determinará as primeiras providencias a serem tomadas, acompanhada das demais peças.

Manoel Messias Barbosa (2004, p.29), ensina que:

Na portaria de instauração do inquérito policial, a autoridade fará constar descrição objetiva do fato considerado como ilícito, com preliminar indicação 
de autoria ou da momentânea possibilidade de apontá-la, e ainda, a classificação provisória do tipo penal alusivo aos fatos.

b) Auto de prisão em flagrante: quando determinado sujeito for surpreendido, em qualquer das modalidades de flagrante, cometendo um delito, será preso em flagrante. $\mathrm{O}$ auto de prisão em flagrante é uma peça competente a inaugurar um inquérito policial, o qual tem a mesma função da portaria referida no item anterior.

c) Por requisição do Ministério Público ou do juiz: tendo estes o conhecimento do delito, poderá requisitar à autoridade policial que seja instaurado o inquérito para apuração dos fatos, e esta não poderá o rejeitá-la, pois a requisição emanada do Juiz ou do Ministério Público tem caráter ordenatório, ou seja, trata-se de uma ordem. Isto ocorre, não por que a autoridade policial é subordinada hierarquicamente aos requisitantes, mas, por que esta possui "o dever funcional de instaurar investigação tão logo tenha conhecimento de alguma prática potencialmente criminosa. Dessa forma, a requisição funcionaria como notitia criminis indireta". (BONFIM, 2012, p.154)

d) Por requerimento da vítima: quando ocorrer um delito cuja ação penal esteja condicionada à representação do ofendido ou de seu representante legal, a autoridade policial só poderá instaurar o inquérito com a devida representação, que será reduzida a termo e juntada aos autos. A vítima deverá demonstrar a vontade de representar no prazo de seis meses, sob pena decadência.

Nos crimes de ação penal privada, manifestada a vontade da parte ofendida, deverá ela oferecer o máximo de elementos para que o inquérito policial se dê por completo, bem como o rol de testemunhas à polícia e se caso já possuir tais elementos, o ofendido poderá desde logo oferecer queixa crime, dando inicio à ação penal.

Em se tratando de crimes de iniciativa privada, Capez (2014, p.128), de forma objetiva esclarece que:

A instauração do inquérito policial pela autoridade pública depende de requerimento escrito ou verbal, reduzido a termo neste ultimo caso, do ofendido ou de seu representante legal, isto é, da pessoa que detenha titularidade da respectiva ação penal. Nem sequer o Ministério Público ou a autoridade judiciária poderão requisitar a instauração da investigação.

\section{O VALOR PROBATÓRIO DO INQUÉRITO POLICIAL}

Neste ponto adentramos na problemática do trabalho que é elucidar qual o valor probandi do inquérito policial. Não há na doutrina posicionamento exato, enquanto uns afirmam que o inquérito não tem capacidade para influir na convicção do magistrado no momento da prolação da 
sentença, por se tratar de peça meramente informativa e não se sujeitar ao contraditório, outros defendem que este deveria ter força para que pudesse o juiz usá-lo como fundamento de eventual condenação.

Para Antônio Alberto Machado (2013, p. 121):

não seria de se admitir uma condenação criminal lastreada tão somente nos elementos produzidos no âmbito do inquérito. É por isso que se afirma que os elementos de provas ali colhidos devem ser ratificados em juízo, sob o pálio do contraditório e da ampla defesa.

A doutrina majoritária tem considerado como prova válida produzida na fase de investigação as provas cautelares, as provas não repetíveis e as provas antecipadas. Destarte, Luiz Flávio Gomes (2012, p.01) conceitua estes três tipos de provas:

a) provas irrepetíveis: são as de iminente perecimento, que são colhidas durante o inquérito policial por inviabilidade lógica da sua realização na fase processual: por exemplo, a constatação da embriaguez para os efeitos do artigo $\underline{306}$, CTB.

b) provas cautelares: pautadas pela necessidade e urgência, como a interceptação telefônica, por exemplo.

c) incidente de produção antecipada de prova: instaurado perante o juiz, mesmo durante o trâmite do inquérito, já fixando a prevenção. Cabe ao juiz convocar as futuras partes do processo e promover o respeito ao contraditório e ampla defesa.

Priscila Felix Silva Loureiro, (2014, p.01) discorre que no atual Processo Penal Brasileiro adota-se o sistema de livre convencimento motivado, ou seja, aquele em que o juiz se baseia nas provas acostadas aos autos, valorando-as conjuntamente, sem valor pré-determinado e fundamentando sua decisão. Porém, já existiu o sistema da certeza moral e da tarifação das provas, o qual se baseava apenas nos princípios morais do juiz, sua própria convicção.

Com a nova redação do artigo 155 do Código de processo penal, operada pela reforma à Lei no 11.690/08, que alterou o capítulo referente às provas no Código de Processo Penal, vem causando insatisfação aos doutrinadores, pois, a intenção da reforma era desconsiderar valoração das provas produzidas no inquérito, contudo, não foi o que aconteceu. Ao estabelecer que as decisões do magistrado não podem fundamentar-se exclusivamente nos elementos informativos colhidos na investigação, deu a entender que se as provas produzidas no inquérito se forem lastreadas em outros elementos probatórios poderão ser livremente valoradas.

Sendo assim, conclui Cristiano Luís Ferreira (2009, P. 01):

Assim, entende-se que a reforma de 2008 ao invés de enfraquecer o inquérito policial, valorizou-o, pois reafirmou sua importância dentro do cenário da 
persecução penal. Só a colheita e tratamento adequado das provas permitirão a realização da justiça e justiça sempre deve ser o fim buscado pela sociedade.

Desta forma, entende-se que as provas produzidas durante a investigação preliminar não deveria servir de lastro para formar a convicção do juiz, entretanto, não é o que ocorre, pois, com a modificação ocorrida na legislação, houve uma má interpretação dos doutrinadores e, esta acabou atribuindo um valor maior ao inquérito, podendo o juiz valer das provas ali produzidas para proferir sua sentença.

\section{CONCLUSÃO}

O inquérito policial hoje vem se mostrando como um verdadeiro instrumento de proteção social, tendo a polícia judiciária atuado como genuína guardiã da sociedade.

No curso da investigação policial, poder-se-á ser desvendado o autor do delito, as circunstâncias do caso e o comportamento da vítima, ou até mesmo que o crime não se configurou. Com isso, objetiva-se chegar a uma conclusão certa e não permanecer em dúvida perene.

Muito embora a doutrina e a jurisprudência desprezem a valoração das provas produzidas no inquérito, havendo necessidade de serem reproduzidas em juízo sob o crivo do contraditório e da ampla defesa, pode-se concluir que, com a alteração do artigo 155 do Código de Processo Penal, ao invés de dispensar a força probatória do inquérito, este acabou sendo valorizado.

Além do juiz poder utilizar-se do princípio do livre convencimento motivado, o qual não predetermina valor a qualquer tipo de prova, podendo sentenciar de acordo com seu convencimento, o artigo supramencionado confere a ele a possibilidade de valer-se, inclusive, das provas produzidas na investigação criminal para proferir sua sentença, atribuindo, desta forma, valor ao inquérito policial, rebatendo toda discussão doutrinária.

\section{REFERÊNCIAS}

BARBOSA, Manoel Messias. Inquérito Policial: doutrina, prática e jurisprudência. 4 ed. São Paulo: Editora Método, 2004.

BONFIM, Edilson Mougenot. Curso de processo penal. 7 ed. São Paulo: Saraiva, 2012.

CAPEZ, Fernando. Curso de processo penal. 21 ed. São Paulo: Saraiva, 2014.

FERREIRA, Cristiano Luiz Ferreira. Valor probatório do inquérito policial e a reforma processual de

2008. Disponível em: <http://lfg.jusbrasil.com.br/noticias/2022549/valor-probatorio-do- 
inquerito-policial-e-a-reforma-processual-de-2008-cristiano-luiz-ferreira> Acesso em: 10 ago. 2015.

GOMES, Luiz Flávio. O que se entende por elementos migratórios no processo penal? 2012. Disponível em: <http://professorlfg.jusbrasil.com.br/artigos/121928539/o-que-se-entende-porelementos-migratorios-no-processo-penal> Acesso em: 15 ago. 2015

LIMA, Marcellus Polastri. Manual de Processo Penal. 3 Ed. Rio de Janeiro: Editora Lumen Juris, 2009.

LOUREIRO, Priscila Felix Silva. Provas irrepetíveis, cautelares, antecipadas e suas nuances no inquérito policial. 09/2014. Disponível em: <http://jus.com.br/artigos/32193/provas-irrepetiveiscautelares-antecipadas-e-suas-nuances-no-inquerito-policial\#ixzz3ibryR6EF http://jus.com.br/artigos/32193/provas-irrepetiveis-cautelares-antecipadas-e-suas-nuances-noinquerito-policial\#ixzz3ibryR6EF> Acesso em: 10 ago 2015

MACIEL, José Fabio Rodrigues. Inquérito policial no brasil.30/06/2006. Disponível em: <http://www.cartaforense.com.br/conteudo/colunas/inquerito-policial-no-brasil---origens/415>. Acesso em: 05 ago. 2015

$\mathrm{NUCCl}$, Guilherme de Souza. Manual de processo penal e execução penal. 5 ed. São Paulo: Revista dos Tribunais, 2008.

PICOLIN, Gustavo Rodrigo. Surgimento do inquérito policial. 29/01/2007. Disponível em: <http://www.jurisway.org.br/v2/dhall.asp?id_dh=156 >. Acesso em: 05 ago. 2015

TOURINHO FILHO, Fernando da Costa. Manual de processo penal. 13. ed. São Paulo: Saraiva, 2010. 